\title{
Casting Activity of Scherotheca gigas in No-Till Mediterranean Soils: Role in Organic Matter Incorporation and Influence of Aridity
}

\author{
Paloma Bescansa, Iñigo Virto, Oihane Fernández-Ugalde, \\ María José Imaz, and Alberto Enrique \\ Área Edafología y Química Agrícola, Departamento Ciencias del Medio Natural, Universidad Pública de Navarra, \\ Campus Arrosadia, 31006 Pamplona, Spain
}

Correspondence should be addressed to Iñigo Virto, inigo.virto@unavarra.es

Received 31 July 2009; Revised 24 November 2009; Accepted 24 December 2009

Academic Editor: Thilagavathy Daniel

Copyright (c) 2010 Paloma Bescansa et al. This is an open access article distributed under the Creative Commons Attribution License, which permits unrestricted use, distribution, and reproduction in any medium, provided the original work is properly cited.

The behaviour of earthworms, their role in organic matter incorporation into the soil, and the influence of aridity in such processes in arid and semiarid regions have scarcely been studied. In this study, physico-chemical analyses of the casts and the surrounding no-till agricultural soils of three experimental sites representing an aridity gradient in Navarre (NW Spain) were done. The casts were formed by the activity of the only anecic species, Scherotheca gigas (Dugès, 1828), ubiquitous in no-till soils in this region. We observed a significant depletion of clay and higher concentration of total organic $\mathrm{C}$ and labile $\mathrm{C}$ in the form of particulate organic matter (POM) in the casts as compared to the surrounding soil, suggesting selective ingestion of soil by S. gigas. This, together with the observation of increased concentration in POM with increasing aridity, suggests a major role of this species in the observed progressive gains of organic $\mathrm{C}$ stocks in no-till soils in the region.

\section{Introduction}

It is well known that the abundance of earthworms in the soil depends on soil properties and on climate. Most of the studies related to the earthworms behaviour are from the tropical and subhumid temperate soils. Their behaviour in more limiting conditions, such as agricultural soils in semiarid or arid regions, has been less studied [1]. Some particularities of earthworms such as large body size, slow growth rate, ability to feed on soils poor in organic matter, occupying deeper soil profile, have been described in Mediterranean soils [2]. However, our knowledge is still limited. For instance, in the Iberian Peninsula, much less information on earthworm occurrence and activity exists for the Mediterranean domain than for the more humid NW area [3]. The reality is that in the majority of agricultural soils with Mediterranean type of climate, like in the Ebro Valley of Spain, located in the Mediterranean-IberianLevantine biogeographical superprovince [2], earthworms are scarce and often absent when tillage is intense [4].

It is also well known that, in general, when tillage is reduced earthworm activity increases. No-till and other methods of conservation tillage such as chisel plowing can thus increase earthworm populations [5]. Decreased tillage disturbances particularly benefit anecic species, which can move in the same burrow between deeper soil layers and the soil surface in search of food. This is so because when tillage destroys these burrows, some earthworms may not have the energy reserve needed to form a new burrow to their food source [6]. Previous studies in rainfed agricultural soils, cropped to cereals in the Ebro Valley (Navarra, Spain), provided evidence of increased earthworm density and biomass with reduced tillage $[7,8]$. The three species commonly found in no-till soils in the area are Allolobophora rosea, Scherotheca gigas, and Prosellodrilus praticola. S. gigas (Dugés 1828) is the only anecic species to deposit cast on the soil surface. Though this species is widespread in the area, it 
has a narrow geographical distribution worldwide [9]. In a study in the role of earthworms in soil aggregate formation, S. gigas was cited by Bouché and Al-Addan [10] as one of the most abundant species in a dry grassland on calcareous soil.

As for most earthworm species, soil moisture and temperature affect the activity of $S$. gigas. Field observations led us to distinguish two periods of surface casting activity over the year [8], each interrupted by a period of inactivity in January/February and June/September. As observed in other semiarid areas [11], during the dry summer months the species undergo diapause and cannot be found at the soil surface.

The contribution of earthworms to organic matter incorporation into the soil can be studied by comparing surface casts and the surrounding soil. Properties of surface casts usually differ from those of the bulk soil, but contradictory findings have been reported. Differences are related to the type of soil [12] and/or to earthworm species [13]. Brown et al. [14] have described in detail the role of earthworms in organic matter stabilization. These authors consider that the inclusion of the active fractions of the soil organic matter (SOM) into earthworm casts can contribute to its protection and stabilization when casts dry up, a process that can happen within hours or days after its deposition. It has also been demonstrated that soil management can greatly influence this process [15-17].

The protection of SOM from biological degradation in surface casts $[18,19]$ has a special significance for soils with high mineralization rates and low contents in SOM, as is the case for the soils of the Ebro Valley. In addition, soils rich in calcium carbonate also contribute to the persistence of casts over longer time periods and thus to long-time SOM protection.

The purpose of this study was to gain knowledge on the behavior of $S$. gigas in no-till carbonated Mediterranean soils by studying its role in the incorporation and preservation of organic matter into the soil and the influence of aridity in this process.

\section{Methodology}

2.1. Study Sites. The study was conducted at three longterm experimental sites that include different soil management treatments in the Ebro Valley in Navarre (NE, Spain). These sites were located in Pamplona $\left(42^{\circ} 47^{\prime} 32^{\prime \prime} \mathrm{N}\right.$; $\left.1^{\circ} 37^{\prime} 54^{\prime \prime} \mathrm{W}\right)$, Olite $\left(42^{\circ} 27^{\prime} 33^{\prime \prime} \mathrm{N} ; 1^{\circ} 41^{\prime} 07^{\prime \prime} \mathrm{W}\right)$, and Santacara $\left(42^{\circ} 23^{\prime} 44^{\prime \prime} \mathrm{N} ; 1^{\circ} 32^{\prime} 32^{\prime \prime} \mathrm{W}\right)$. Only the plots under no-till (NT) of each experimental site were chosen for earthworms and soil sampling. This was done because greater earthworm activity has been observed in the area in NT plots [8]. The three sites contain carbonated soils which are cropped to rainfed barley (Hordeum vulgare L.), but differ in some soil properties and, especially, in their agroclimatic characteristics (Table 1). They represent an aridity gradient because average rainfall is greater in Pamplona (Mediterranean sub-humid type of climate) and decreases southward to Olite (semiarid Mediterranean) and then Santacara (arid Mediterranean), while average annual temperatures and reference evapotranspiration $\left(\mathrm{ET}_{0}\right)$ increase in the same order.

A direct seeder that opens a seed-furrow 30 to $50 \mathrm{~mm}$ deep is used for barley seeding in fall in the studied NT plots at the three sites, using similar seeding doses $(\sim 160 \mathrm{~kg} / \mathrm{ha})$ and fertilization treatments. Average barley yield decreases with increasing aridity (Table 1).

2.2. Sampling Methods. As already mentioned, earthworm activity in the region is clearly seasonal, and coincides with the two rainfall peaks and mild temperatures observed in spring and fall. Three field NT replicates (plots) were sampled in November 2007 at each study site, in order to identify the earthworm species present in the soil. Two soil blocks $(0.20$ by 0.20 by $0.20 \mathrm{~m})$ were taken in each plot. Earthworms were sampled by hand-sorting and counted in the field. Individuals were fixed with ethanol-formalin, and preserved in 10\% formalin [20]. They were classified at the Department of Ecology and Animal Biology of the University of Vigo (Spain). Thirty to 50 individuals of $S$. gigas were found per square meter at the three study sites. Considering the size and the ability of this species to dig deep into the soil, these numbers are likely an underestimation of the actual abundance of $S$. gigas in the studied soils. It was observed that $S$. gigas was the only anecic species found, which indicates that surface casts present in the three soils were created by individuals of this species. This also illustrates the ubiquity of this species in NT soils in the region, regardless of soil characteristics and agroclimatic conditions.

Simultaneously, four replicates of surface earthworm casts were collected at three random points in the NT plots at each study site. Casts were air-dried, ground to pass through a 2-mm sieve and stored for further analyses.

Soil $(0-30 \mathrm{~cm})$ was sampled using an Edelman-type auger. Disturbed subsamples were collected at four random points per plot, and combined to obtain a composite sample per plot, so that three field replicates were analyzed at each site. Samples were air-dried and ground to pass through a 2-mm sieve.

2.3. Laboratory Analyses. Clay, total organic $\mathrm{C}$ content, and $\mathrm{C}$ in the form of particulate organic matter (C-POM [21]) were determined both in the casts and the bulk soil. Clay content was determined by the pipette method [22], using a modified Robinson pipette. Samples were chemically dispersed with a solution of $5 \%\left(\mathrm{NaPO}_{3}\right)_{6}$ before analysis. Due to the elevated carbonate content of the three soils (Table 1), wet oxidation was used to analyze total organic C [23].

Particulate organic matter is acknowledged to represent the most labile fraction of organic matter in the soil, and it is related to the formation of stable aggregates [24]. For this study, POM was isolated by dispersion and sieving of $10 \mathrm{~g}$ of air-dried soil, as described by Marriott and Wander [25]. Briefly, samples were dispersed with $150 \mathrm{~mL}$ of $5 \%$ $\left(\mathrm{NaPO}_{3}\right)_{6}$ and the fraction $>53 \mu \mathrm{m}$ (which includes the POM and sand-size mineral components of the soil) was collected on a $53-\mu \mathrm{m}$-opening polycarbonate mesh (Gilson Co. Inc., 
TABle 1: Agroclimatic and soil characteristics of the three studied sites.

\begin{tabular}{lccc}
\hline Study site & Pamplona & Olite & Santacara \\
\hline Rainfall $(\mathrm{P}, \mathrm{mm})$ & 830 & 525 & 423 \\
Evapotranspiration $*\left(\mathrm{ET}_{0}, \mathrm{~mm}\right)$ & 972 & 1163 & 1145 \\
${\mathrm{P} / \mathrm{ET}_{0}}^{\circ}$ & 0.85 & 0.45 & 0.37 \\
Temperature $\left({ }^{\circ} \mathrm{C}\right)$ & 12.4 & 13.5 & 14.2 \\
\hline Average barley yield $\left(\mathrm{tgrain} \mathrm{ha}^{-1}\right)$ & 3.93 & 3.70 & 2.75 \\
\hline Soil type $(\mathrm{FAO}, 2003)$ & Calcic Cambisol & Calcic Cambisol & Haplic Calcisol \\
$\mathrm{pH}(0-30 \mathrm{~cm})(1: 2.5)$ & 8.63 & 8.25 & 8.48 \\
$\mathrm{CaCO}_{3}(0-30 \mathrm{~cm})\left(\mathrm{g} \mathrm{kg} \mathrm{soil}^{-1}\right)$ & 252 & 359 & 363 \\
\hline
\end{tabular}

* Reference evapotranspiration, (FAO).

Columbus, $\mathrm{OH}$ ) after 3 rinses with distilled water, and then oven-drying at $50^{\circ} \mathrm{C}$. Samples were then ground to a powdery consistency before measuring their $\mathrm{C}$ content to determine POM-C by wet oxidation [23].

2.4. Statistics. Data are presented as \pm standard error of the mean for casts and soil characteristics. Data were analysed using ANOVA (univariate linear model), and means were compared among the three soils and between soil and casts at each study site using significant differences. Post hoc analysis was performed by Duncan's multiple range test. Significant results are based on a probability level of $P<.05$. All statistical analyses were performed using the SPSS 16.0 software [26].

\section{Results and Discussion}

3.1. Role of S. gigas in the Incorporation of Organic Matter into the Soil. Lower clay contents were observed in the S. gigas casts than the bulk soil in the three studied fields (Table 2). Our findings support thus the suggestion of Schrader and Zhang [27] that selective particle ingestion by earthworms leading to increased clay contents in casts than in the surrounding soil [28] appears to be confined to sandy soils, and/or might be more common in other smaller species of earthworms than the anecic S. gigas. An alternative explanation could be the existence of ultra-stable silt-size or sand-size aggregates in the casts, which would resist chemical dispersion.

Results from the analysis of the organic components of casts and bulk soils revealed that $S$. gigas casts contained more total organic C and POM than the soil (Table 2), as has also been reported through other studies [14]. More interestingly, the percentage of $\mathrm{C}$ in the form of POM was also greater within the casts than in the soil at the three studied sites, suggesting a selective ingestion of the more edible fresh plant residues and labile organic materials by S. gigas [14]. This finding is of special importance in the studied soils, which are naturally poor in organic matter, because POM entrapped within casts is likely to be more protected against microbial activity than elsewhere in the soil [12]. Guggenberger et al. [29] reported that the incorporation of organic matter in the casts of anecic earthworms on an Oxisol occurred preferentially in the form of POM. They related this to the higher aggregate stability observed in the casts in comparison to the surrounding soil. They further suggested that the mechanisms that protect organic matter from decomposition during aggregate formation and stabilization, as also described by Tisdall and Oades [30] and Six et al. [24], can be enhanced or facilitated by earthworm casting activity. Direct incorporation of POM into stable microaggregates through earthworm transit in the soil has also been described by Pulleman et al. [15] as an "alternative pathway" to the microbial-mediated one for the stabilization of POM by occlusion within microaggregates in undisturbed soils.

Long-term stabilization of organic matter occluded within aggregates inside earthworm casts is in fact possible [31] and depends on the type of soil [32], earthworm species [33], the age of casts, the way they dry [34-36], and the level of disturbance to which casts are subjected [12]. A number of studies have shown that the quantity of organic matter incorporated into the soil by earthworms also significantly affects the stability of casts. In the present study elevated clay and carbonates contents of the soils allow for overall high aggregate stability [8]. In Olite and Santacara, scarce rainfall and high average temperatures cause a rapid dehydration of casts and, as a result, intact earthworm casts are observed several months after their formation at these two study sites. In addition, NT techniques ensure low disruption of the soil surface and protection against raindrops by the mulch. Considering the observed contribution of S. gigas to POM preservation within the casts, the contribution of this species to the stabilization of organic materials and the overall increase of organic C observed in NT soils in the region $[37,38]$ is likely to be of importance.

3.2. Influence of Aridity in the Behavior of S. gigas. Differences related to the agroclimatic context of the three studied soils were found in the enrichment factor and composition of casts in relation to bulk soil (Table 3 ).

While in all the three sites casts contained less clays than the bulk soil, the relative amount of clay found in the casts of the more humid soil in Pamplona was significantly greater than in Olite and Santacara (Table 3). If we consider that the soil clay content was similar in Pamplona and Santacara and 
TABLE 2: Content in clay, total organic C, and C in the form of POM (C-POM) in bulk soil samples and in Scherotheca gigas casts at the three study sites. Values marked with $*$ are significantly different $(P<.05)$ between soil and casts for each parameter and site. Values followed by the same letter in the same row belong to the same Duncan's homogeneous groups $(P<.05)$ for each parameter among sites. Means \pm standard error $(n=3)$.

\begin{tabular}{llcrr}
\hline Study site & & Pamplona & Olite & Santacara \\
\hline \multirow{2}{*}{ Clay $(\mathrm{g} / \mathrm{kg})$} & Soil & $306.2 \pm 6.7^{* \mathrm{a}}$ & $426.2 \pm 2.04^{* \mathrm{~b}}$ & $284.8 \pm 2.6^{* \mathrm{a}}$ \\
& Casts & $233.4 \pm 2.5^{* \mathrm{~b}}$ & $234.8 \pm 22.2^{* \mathrm{~b}}$ & $165.2 \pm 6.8^{* \mathrm{a}}$ \\
\hline \multirow{2}{*}{ Total OC $(\mathrm{g} / \mathrm{kg})$} & Soil & $14.03 \pm 0.42^{* \mathrm{~b}}$ & $14.32 \pm 0.66^{* \mathrm{~b}}$ & $12.55 \pm 0.22^{* \mathrm{a}}$ \\
& Casts & $21.93 \pm 0.78^{* \mathrm{a}}$ & $26.23 \pm 1.81^{* \mathrm{~b}}$ & $19.13 \pm 0.36^{* \mathrm{a}}$ \\
\hline \multirow{2}{*}{ C-POM $(\mathrm{g} / \mathrm{kg})$} & Soil & $2.77 \pm 0.12^{* \mathrm{ab}}$ & $3.66 \pm 0.52^{* \mathrm{~b}}$ & $2.16 \pm 0.07^{* \mathrm{a}}$ \\
& Casts & $6.47 \pm 0.37^{* \mathrm{a}}$ & $9.52 \pm 0.27^{* \mathrm{~b}}$ & $8.47 \pm 0.89^{* \mathrm{ab}}$ \\
\hline \multirow{2}{*}{ C-POM/Total OC } & Soil & $0.20 \pm 0.01^{* \mathrm{a}}$ & $0.25 \pm 0.03^{* \mathrm{~b}}$ & $0.17 \pm 0.00^{* \mathrm{a}}$ \\
& Casts & $0.29 \pm 0.01^{* \mathrm{a}}$ & $0.36 \pm 0.02^{* \mathrm{ab}}$ & $0.44 \pm 0.04^{* \mathrm{~b}}$ \\
\hline
\end{tabular}

TABLe 3: Cast-to-soil ratios of clay, total organic C, and C in the form of POM (C-OPM) at the three study sites. Values followed by the same letter in the same row belong to the same Duncan's homogeneous groups $(P<.05)$ for each parameter among sites. Means \pm standard error $(n=3)$.

\begin{tabular}{llccc}
\hline Study site & & Pamplona & Olite & Santacara \\
\hline & Clay & $0.76 \pm 0.02^{\mathrm{b}}$ & $0.53 \pm 0.07^{\mathrm{a}}$ & $0.59 \pm 0.02^{\mathrm{a}}$ \\
Cast-to-soil ratios & Total OC & $1.57 \pm 0.11$ & $1.82 \pm 0.12$ & $1.50 \pm 0.04$ \\
& C-POM & $2.44 \pm 0.19^{\mathrm{a}}$ & $3.00 \pm 0.37^{\mathrm{ab}}$ & $4.01 \pm 0.45^{\mathrm{b}}$ \\
\hline
\end{tabular}

greater in Olite (Table 2), this finding suggests that climate is a more important factor for this relative diminution in the clay content of the casts than the soil texture itself. Not much information is available on the influence of climate on the burrowing and casting activity of any particular earthworm species. In temperate areas, annual variations in the casting activity of anecic species (Lumbricus terrestris) have been described as related to rainfall and soil moisture [39].

In tropical semiarid areas, no earthworms are found during the dry seasons in soils that show earthworm activity during the rainy season [17].

Higher moisture in the soil in Pamplona than in the more aridic Olite and Santacara could be one reason for the enhanced casting activity and thus for more intense remixing of the casts with bulk soil. Lower concentration of carbonates in this soil (Table 1) probably also favored the formation of less cemented casts with less nondispersible sand- and siltsize aggregates within casts. Further research is needed in this sense.

Regarding the incorporation of organic materials into the casts, it was observed that the enrichment factor in total organic $\mathrm{C}$ in the casts compared to bulk soil was similar among the three studied soils, but a clear and significant trend towards higher enrichment ratios in POM was observed with increasing aridity (Table 3 ). The role of $S$. gigas in incorporation of POM was most significant in the arid soils of Santacara, which had the lowest total SOC and POM values as well as the lowest crop yield (Table 1), as compared to the other two sites. This more evident preferential ingestion of POM in this soil probably is due to fresh stubble being the most significant available source of $\mathrm{C}$ in this field.

\section{Conclusions}

By studying the composition of surface casts of S. gigas and the surrounding soil under different agroclimatic conditions in NT fields in the Ebro Valley, we found that this species has an important role in the incorporation of organic matter, and in particular of the most labile fractions, to the soil. The casting activity of $S$. gigas seems thus related to the observed progressive increments of organic C stocks in NT soils in the region. We also found a proportionally greater enrichment in labile organic particles in casts with increasing aridity, which suggests that the importance of S. gigas in organic matter stabilization under NT increases with aridity in the region. The relationship between climate, $S$. gigas casts texture, and organic C content remains however incompletely understood and merits further research.

\section{Acknowledgments}

C. González and M. Moriones are thanked for their technical laboratory assistance, and the Instituto Nacional de Investigación Agraria y Agroalimentaria (INIA, Spanish Agency) is acknowledged for funding this study in the framework of the Research Call "Acción: Sumideros Agroforestales de Efecto Invernadero" of the National Program I+D+i (Project no. SUM 2006-00012-00-00). The authors are grateful also to Professor M. J. Briones (University of Vigo, Spain) for her kind advice and for the classification of earthworms. 


\section{References}

[1] S. W. James, "Systematics, biogeography and ecology of earthworms from Eastern, Central, Southern and Southwestern USA," in Ecology and Biogeography of Earthworms in North America, P. E. Hendrix, Ed., pp. 29-51, Lewis, Boca Raton, Fla, USA, 1995.

[2] J. P. Curry, "Factors affecting the abundance of earthworms in soils," in Earthworm Ecology, C. A. Edwards, Ed., pp. 91-113, CRC Press LLC, Boca Raton, Fla, USA, 2nd edition, 2004.

[3] D. J. Diaz-Cosin, D. Trigo, and R. Mascato, "Earthworms of the iberian peninsula. Species list and some biogeographical considerations," Soil Biology and Biochemistry, vol. 24, no. 12, pp. 1351-1356, 1992.

[4] M. V. Reddy, Management of Tropical Agroecosystems and the Beneficial Soil Biota, Science Publishers, Enfield, NH, USA, 1999.

[5] C. A. Edwards and P. J. Bohlen, Biology and Ecology of Earthworms, Chapman \& Hall, London, UK, 3rd edition, 1996.

[6] P. M. Mele and M. R. Carter, "Impact of crop management factors in conservation tillage farming on earthworm density, age structure and species abundance in south-eastern Australia," Soil and Tillage Research, vol. 50, no. 1, pp. 1-10, 1999.

[7] M. J. I. Briones, P. Bescansa, M. J. Imaz, I. Virto, and A. Enrique, "Effects of different tillage practices on soil properties and earthworm population," in Proceedings of the 8th International Symposium on Earthworms Ecology, p. 169, Krakow, Poland, September 2006.

[8] I. Virto, M. J. Imaz, A. Enrique, W. Hoogmoed, and P. Bescansa, "Burning crop residues under no-till in semiarid land, Northern Spain. Effects on soil organic matter, aggregation, and earthworm populations," Australian Journal of Soil Research, vol. 45, no. 6, pp. 414-421, 2007.

[9] E. Rota, "Fauna Europaea: Lumbricidae, Lumbricinae," Fauna Europaea version 1.1, 2004, http://www.faunaeur.org/.

[10] M. B. Bouché and F. Al-Addan, "Earthworms, water infiltration and soil stability: some new assessments," Soil Biology and Biochemistry, vol. 29, no. 3-4, pp. 441-452, 1997.

[11] M. V. Reddy, V. P. K. Kumar, V. R. Reddy, et al., "Earthworm biomass response to soil management in semi-arid tropical Alfisol agroecosystems," Biology and Fertility of Soils, vol. 19, no. 4, pp. 317-321, 1995.

[12] M. J. Shipitalo and R. Le Bayon, "Quantifying the effects of earthworms on soil aggregation and porosity," in Earthworm Ecology, C. A. Edwards, Ed., pp. 183-200, CRC Press LLC, Boca Raton, Fla, USA, 2nd edition, 2004.

[13] R. J. Haynes, P. M. Fraser, J. E. Piercy, and R. J. Tregurtha, "Casts of Aporrectodea caliginosa (Savigny) and Lumbricus rubellus (Hoffmeister) differ in microbial activity, nutrient availability and aggregate stability," Pedobiologia, vol. 47, no. 5-6, pp. 882-887, 2003.

[14] G. G. Brown, I. Barois, and P. Lavelle, "Regulation of soil organic matter dynamics and microbial activity in the drilosphere and the role of interactions with other edaphic functional domains," European Journal of Soil Biology, vol. 36, no. 3, pp. 177-198, 2000.

[15] M. M. Pulleman, J. Six, A. Uyl, J. C. Y. Marinissen, and A. G. Jongmans, "Earthworms and management affect organic matter incorporation and microaggregate formation in agricultural soils," Applied Soil Ecology, vol. 29, no. 1, pp. 1-15, 2005.

[16] S. J. Fonte, A. Y. Y. Kong, C. van Kessel, P. F. Hendrix, and J. Six, "Influence of earthworm activity on aggregate-associated carbon and nitrogen dynamics differs with agroecosystem management," Soil Biology and Biochemistry, vol. 39, no. 5, pp. 1014-1022, 2007.

[17] M. V. Reddy, V. R. Reddy, P. Balashouri, et al., "Responses of earthworm abundance and production of surface casts and their physico-chemical properties to soil management in relation to those of an undisturbed area on a semi-arid tropical alfisol," Soil Biology and Biochemistry, vol. 29, no. 3-4, pp. 617620, 1997.

[18] F. Binet and R. C. Le Bayon, "Space-time dynamics in situ of earthworm casts under temperate cultivated soils," Soil Biology and Biochemistry, vol. 31, no. 1, pp. 85-93, 1999.

[19] J. K. Whalen, L. Sampedro, and T. Waheed, "Quantifying surface and subsurface cast production by earthworms under controlled laboratory conditions," Biology and Fertility of Soils, vol. 39, no. 4, pp. 287-291, 2004.

[20] G. H. Baker and K. E. Lee, "Earthworms," in Soil Sampling and Methods of Analysis, M. R. Carter, Ed., pp. 359-371, Lewis, Boca Raton, Fla, USA, 1993.

[21] C. A. Cambardella and E. T. Elliot, "Particulate soil organicmatter changes across a grassland cultivation sequence," Soil Science Society of America Journal, vol. 56, no. 3, pp. 777-783, 1992.

[22] P. R. Day, "Particle fractionation and particle-size analysis," in Methods of Soil Analysis, Part I, C. A. Black, Ed., ASA Agronomy Series, no.12, pp. 545-567, American Society of Agronomy, Madison, Wis, USA, 1965.

[23] H. Tiessen and J. O. Moir, "Total and organic carbon," in Soil Sampling and Methods of Analysis, M. Carter, Ed., pp. 187-200, Lewis, Boca Raton, Fla, USA, 1993.

[24] J. Six, H. Bossuyt, S. Degryze, and K. Denef, "A history of research on the link between (micro)aggregates, soil biota, and soil organic matter dynamics," Soil and Tillage Research, vol. 79, no. 1, pp. 7-31, 2004.

[25] E. E. Marriott and M. M. Wander, "Total and labile soil organic matter in organic and conventional farming systems," Soil Science Society of America Journal, vol. 70, no. 3, pp. 950-959, 2006.

[26] SPSS Inc., Statistical software SPSS 16.0. Chicago, Ill, USA, 2008.

[27] S. Schrader and H. Zhang, "Earthworm casting: stabilization or destabilization of soil structure?" Soil Biology and Biochemistry, vol. 29, no. 3-4, pp. 469-475, 1997.

[28] P. Lavelle, F. Charpentier, C. Villenave, et al., "Effects of earthworms on soil organic matter and nutrient dynamics at a landscape scales over decades," in Earthworm Ecology, C. A. Edwards, Ed., pp. 145-160, CRC Press LLC, Boca Raton, Fla, USA, 2nd edition, 2004

[29] G. Guggenberger, R. J. Thomas, and W. Zech, "Soil organic matter within earthworm casts of an anecic-endogeic tropical pasture community, Colombia," Applied Soil Ecology, vol. 3, no. 3, pp. 263-274, 1996.

[30] J. M. Tisdall and J. M. Oades, "Organic matter and waterstable aggregates in soils," Journal of Soil Science, vol. 33, no. 2, pp. 141-163, 1982.

[31] H. Bossuyt, J. Six, and P. F. Hendrix, "Protection of soil carbon by microaggregates within earthworm casts," Soil Biology and Biochemistry, vol. 37, no. 2, pp. 251-258, 2005.

[32] M. McInerney and T. Bolger, "Temperature, wetting cycles and soil texture effects on carbon and nitrogen dynamics in stabilized earthworm casts," Soil Biology and Biochemistry, vol. 32, no. 3, pp. 335-349, 2000.

[33] H. Zhang and S. Schrader, "Earthworm effects on selected physical and chemical properties of soil aggregates," Biology and Fertility of Soils, vol. 15, no. 3, pp. 229-234, 1993. 
[34] J. C. Y. Marinissen and A. R. Dexter, "Mechanisms of stabilization of earthworm casts and artificial casts," Biology and Fertility of Soils, vol. 9, no. 2, pp. 163-167, 1990.

[35] R. Hindell, B. M. McKenzie, and J. M. Tisdall, "Influence of drying and ageing on the stabilization of earthworm (Lumbricidae) casts," Biology and Fertility of Soils, vol. 25, no. 1, pp. 27-35, 1997.

[36] L. Mariani, J. J. Jimenez, E. A. Torres, E. Amézquita, and T. Decaëns, "Rainfall impact effects on ageing casts of a tropical anecic earthworm," European Journal of Soil Science, vol. 58, no. 6, pp. 1525-1534, 2007.

[37] P. Bescansa, M. J. Imaz, I. Virto, A. Enrique, and W. B. Hoogmoed, "Soil water retention as affected by tillage and residue management in semiarid Spain," Soil and Tillage Research, vol. 87, no. 1, pp. 19-27, 2006.

[38] J. Álvaro-Fuentes, J. L. Arrúe, R. Gracia, and M. V. López, "Tillage and cropping intensification effects on soil aggregation: temporal dynamics and controlling factors under semiarid conditions," Geoderma, vol. 145, no. 3-4, pp. 390396, 2008.

[39] R. C. Le Bayon, S. Moreau, C. Gascuel-Odoux, and F. Binet, "Annual variations in earthworm surface-casting activity and soil transport by water runoff under a temperate maize agroecosytem," Geoderma, vol. 106, no. 1-2, pp. 121-135, 2002. 

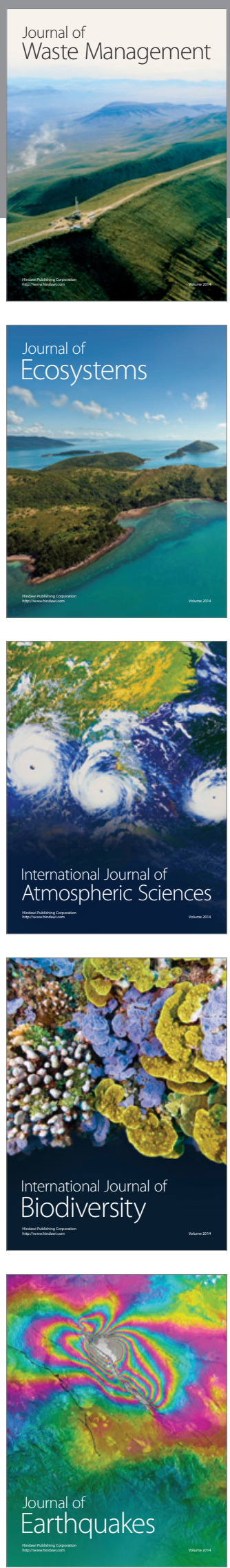
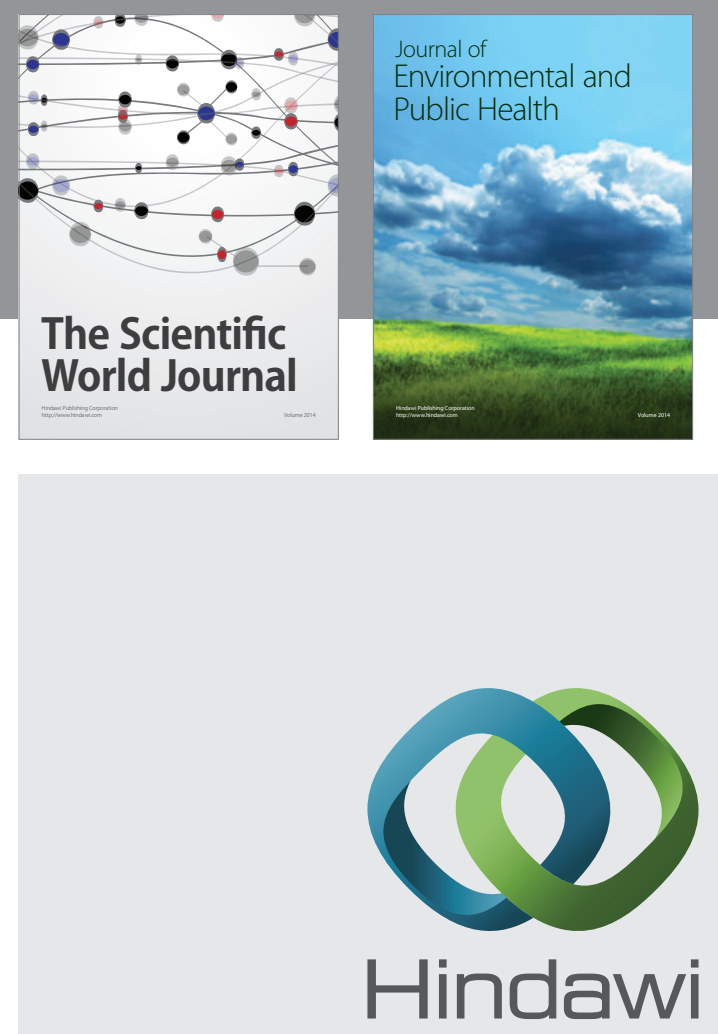

Submit your manuscripts at

http://www.hindawi.com
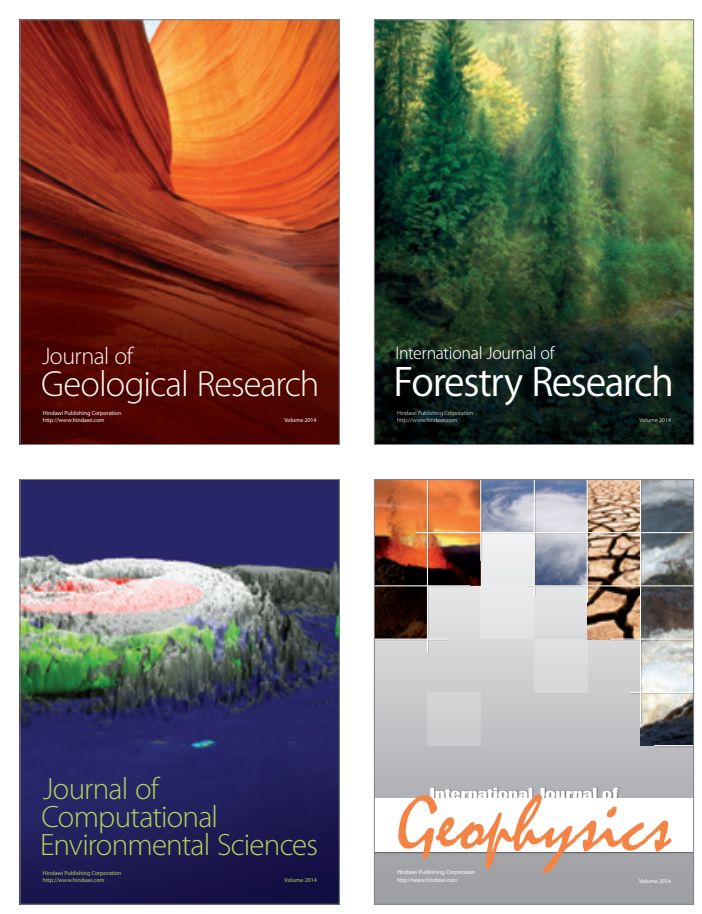
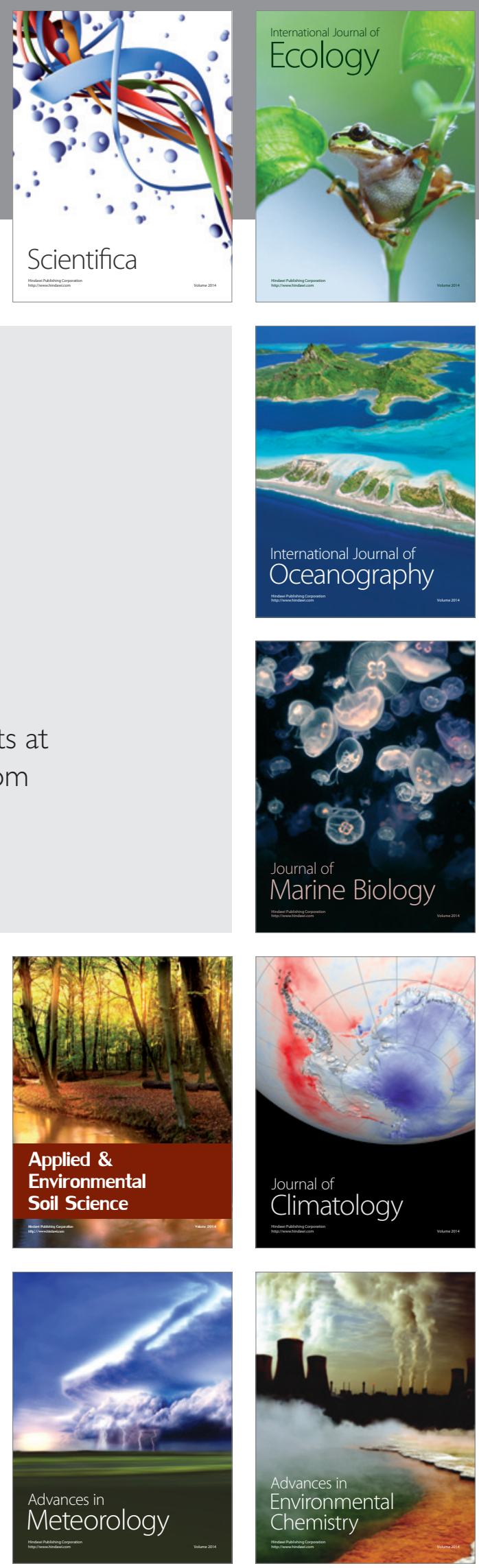